\title{
Inca Inchi Nuts: A Potential Replacement Crop for Opium Among Subsistence Farmers in Kachin State
}

\author{
Jem Lomethong ${ }^{1} \&$ John Walsh ${ }^{2}$ \\ ${ }^{1}$ School of Management, Shinawatra University, Thailand \\ ${ }^{2}$ School of Business and Management, RMIT, Vietnam \\ Correspondence: John Walsh, School of Business and Management, RMIT Vietnam, Handi Resco Building, 521 \\ Kim Ma, Ba Dinh District, Hanoi, Vietnam. Tel: 84-374-050-621. E-mail: john.walsh2@rmit.edu.vn
}

Received: February 15, 2019

doi:10.5539/ass.v15n4p79
Accepted: March 5, $2019 \quad$ Online Published: March 29, 2019

URL: https://doi.org/10.5539/ass.v15n4p79

\begin{abstract}
The Kachin people of northern Myanmar have been fighting for independence for decades. To fund the political and military struggle, the growth and sale of opium has been used. However, narcotics usage has become a scourge in Kachin society as it has been around the world and there have been increasing attempts to eradicate growth and dampen demand. For opium eradication to be successful and sustainable, farmers must be provided with alternative crops that can provide a decent level of income an which are suitable for prevailing agricultural conditions. One possible such crop is the Inca Inchi nut that originally was found in upland South America. The nut provides a nutritious oil with many benefits to health and has been successfully marketed in the form of beverages, cosmetics and medicinal products. This case study considers the possibility of using Inca Inchi nuts across Kachin State as part of an extensive opium replacement programme.
\end{abstract}

Keywords: crop replacement, Inca Inchi nuts, Kachin, opium, subsistence agriculture

\section{Introduction}

The Kachin people are part of an ethnic group of Jinghpao peoples who are located across northern Myanmar and southern China. They occupy in part a liminal space which does not match national borders (Dean, 2005), meaning that the Kachin desire for independence or autonomy is partly imaginary in nature and impractical to create, given political realities.

Left as part of Burma (now Myanmar) after decolonisation, Kachin people have fought for freedom as they see it from the central government and its armed representative the Tatmadaw. The history of Burma has been characterised as one of repeated attempts by the lowland Burman majority to dominate the peoples of the northern upland areas, who lives in places where large amounts of natural resources are congregated (Callaghan, 2009). Kachin resistances led to the creation of a political arm, the Kachin Independence Organization (KIO) and a military wing, the Kachin Independence Army (KIA). To finance the struggle, Kachin people have used locally mined jade and gold products in unofficial trade but those markets have since been shut down (Lintner, 2002, p. 268 ) and, as a result, the production and distribution of opium and its products became the principal means of revenue generation. Opium poppies have been grown in northern mainland Southeast Asia throughout recorded history and their use was permitted under Buddhist precepts in moderation for medicinal use. However, opium production entered into industrial scale production at the time of the Second American War in Indochina (Vietnam War) and the Golden Triangle entered infamy as a result. This region favours illicit production activities because of the "... rugged hills and mountains, heavy monsoon rains, and lack of transport infrastructures" have all acted to limit the ability of central states to enforce their will there (Choavy, 2013). Subsistence farmers in Kachin State and elsewhere continue to grow opium as a second crop in spite of numerous attempts by national and international forces to suppress them because opium offers better prices than available alternatives and because buyers will come to them, thereby removing the problem of getting goods to markets in lands without roads. There are more than 40,000 hectares of land under opium cultivation in Myanmar and that includes Shan State and Pa-O Self-Administered Zone (Pwint, 2018).

Nevertheless, opium growing is not just illegal but brings great misery to local communities where its use has spread considerably. It has spread among discontented and under-employed young people, long distance truck 
drivers and fishers and among those people doing dangerous jobs such as gold and jade mining and scavenging the peripheries of such mines. In some mining activities, many of which are unregistered, wages are paid in part in opium to help people survive the misery of the daily drudgery. Opposition within Kachin State to the spread of drug use is led by religious groups such as Patjasan - many Kachin people are Baptists - which uses eradication and rehabilitation programmes in towns and cities in the State (Verbruggen, 2016). However, eradication of narcotics production is unlikely to be successful without suitable alternative production strategies being put in place. Subsistence farmers growing opium do so in part because they are familiar with the method of cultivation and, when they have been victims of suppression, they may have borrowed money for the next crop, thereby potentially becoming indebted over the long run. Opium growing in some areas is pursued until the land is exhausted and has become covered with the coarse grass, imperata, which is a barrier to future fertility (Cooper, 1979). Consequently, a successful crop replacement programme must coordinate various different elements and ensure its sustainability over a period of years.

This paper reports on a programme of qualitative research involving personal interviews in Kachin State or with the diaspora of Kachin people living in Thailand and other countries, as well as other relevant experts. This research supplements years of ethnographic observation in Kachin State itself and a study of relevant secondary literature. The transcripts of the interview were entered into a suitable database with the contents of the research journal and other relevant information. The contents of the database were subjected to content analysis and the results of the analysis are presented in this paper.

\section{Crop Replacement Programmes}

Drug eradication programmes around the world show only very limited success with low risks to farmers who can adopt to the situation through strategies such as relocation and replanting. Crop substitution projects became integrated rural development projects and then alternative development projects, which indicates the relative failures of different approaches to the problem (Farrell, 1998). The alternative development approach involves the cooperation of agencies involved with law enforcement, community development and demand reduction. It has proven to be successful in neighbouring Thailand, where some ethnic minority peoples in mountainous areas were also involved in opium growing (Renard, 2001). With royal patronage, farmers were encouraged to grow alternative high-value crops such as coffee, macadamia nuts, baby sweetcorn and others which could be exported or subjected to value adding activities locally. The Doi Tung project, which introduced hilltribe themed coffee shops across the country, has been recognised by the UN Office of Drugs and Crime (UNODC) as a leading example of sustainable alternative livelihood development (SALD) (Apolitical, 2017). The SLD was in part created through this project with the assistance of the Mae Fah Luang Foundation (a not-for-profit non-governmental organization in Thailand under Royal Patronage) and has been defined as: "... a holistic, people-centric development approach with an end vision of providing people with sustainable and licit livelihoods. The model tackles poverty and lack of opportunity, which are the root causes of problems like illicit narcotic crop cultivation, human trafficking, weak social structure, environmental degradation, and the prevalence of infectious diseases (Doi Tung, 2018).”

To make this approach successful in terms of crop replacement, it is necessary that:

- Infrastructure exists which will enable firm-to-market transitions practical;

- Agricultural extension services be provided to support farmers producing varieties with which they are not familiar;

- Assessment of changing conditions and further diversification is maintained so that farmers do not get locked in to unprofitable or overly volatile markets.

Although it is government, with the assistance of NGOs, which would be expected to provide these services in countries around the world, there can be a role for the private sector too, especially when there are limitations to the resources and expertise that government agencies might be able to deploy. In the case of Doi Chaang coffee, for example, it was a Canadian investor who identified the potential in a crop substitution programme that saw villagers on the eponymous mountain growing coffee for local consumption. The investor helped provide up-to-date roasting equipment and developed a supply chain and brand such that the coffee could be sold at retail in supermarkets across North America as well as the opening of themed and branded coffee shops in many countries (Pendergrast, 2015).

Since opium replacement programmes have benefits beyond the profits that might be made from commercial activities, it seems appropriate to have accountancy procedures which are not restricted to a single bottom line figure. It also seems appropriate for investors to provide capital and resources to help make the profit work 
without restricting outcome analysis strictly to financial results. However, such funding sources have yet to be identified.

\section{Inca Inchi Nuts}

Inca Inchi nuts (Plukenetia volubilies linneo) (also known as Sacha Inchi nuts) are fruit that derive from South America, particularly Peru, which have been known, as the name suggests, since the time of the Incas (1438-1572 CE). It is an oily wild nut plant that belongs to the Euphorbiacea family of succulents. Although local people have used the leaves to counter skin disease, investigation of the health-giving properties of the seeds has focused on the properties of the oil that may be extracted from them. The high protein levels and omega 3 and omega 6 content is combined with a tendency to reduce the lipid profile of patients with postprandial lipema and hypercholesterolemia (Nascimento et al., 2013). The oil of the Inca Inchi is high in vitamins A and E. Overall, it is claimed that the oil has many beneficial effects on users. Its oil varies from a clear intense yellow to golden amber in colour and the flavour is mild and savoury. It can be used in cooking, as a salad dressing or simply as a tonic, among other uses.

In its home environment, Inca Inchi flourishes in a temperature range of $10-30^{\circ} \mathrm{C}$ and at an elevation of 70 (lower forest) to 200 (upper forest) metres above sea level. These conditions are comparable to those found in Kachin State and the nuts have also been successfully grown in mountainous parts of Lao PDR. The Maï Savanh Lao Company in Lao PDR manufactures various Sacha Inchi products, including salted roasted seeds, tomyam roasted seeds, roll-on oil, skin and hair oil, oil, butter, praline, chocolate coating, powder, softgel, powder and icing sugar and sacolate (a chocolate-like spread). It compares Inca Inchi nuts favourably in terms of omega oils and total unsaturated fatty acids to sunflower seeds, peanuts, pistachios, cashews and macadamia nuts (Maï Savanh Lao, 2018). The company, Maï Savanh Lao, is a fair trade company founded in 2005 with the intention of helping lift Lao communities out of poverty through adding value to local products (or products that can be produced locally) and branding and distributing them internationally. These products include, in addition to the Inca Inchi goods, green peppercorns, green peppercorns in brine, green salted peppercorns, mack khen (a fragrant bay of the Zanthoxylum family) and hibiscus snacks and puree (Maï Savanh Lao, 2018b). The company also wants to recreate high quality silk production in villages in southern Lao PDR where the capability was lost during wartime and to connect such products with markets in the capital Vientiane and across the border (Maï Savanh Lao, 2018c).

\section{From Farm to Market}

Irrespective of the success or failure of actually growing Inca Inchi nuts, there are various obstacles that have to be overcome before products can be distributed to markets:

- Most Kachin subsistence farmers are hampered by very poor local infrastructure, especially with respect to transportation infrastructure. Physically moving the nuts from the farm to a central collection point will be difficult, expensive and time-consuming;

- Farmers have little if any information about Inca Inchi nuts and lack experience in growing them in changing conditions. Already, the symptoms of global climate change are affecting the ability of farmers to cope with unpredictable rains and the spread of unknown pests and diseases;

- No local organizations such as cooperatives or farmers' production groups (FPGs) exist to help coordinate production from different farms, especially when compared to the prevalence of such organizations for collecting opium and other drugs. There is a diversified firm owned by the KIO which assists in the development of Kachin interests, known as Buga. However, its levels of resources and technical capacity are limited (Mon, 2016). Management experience is also lacking (Inkey, 2018);

- The nuts themselves are commodities in nature and there is a need for professional skills in transforming them into branded products of a suitable quality to be sold in national and regional markets. External support will be needed if this is to take place.

Even if these difficulties are to be overcome, then, there is the perennial business problem of lack of demand and operational difficulties such as low or intermittent cash flow. It is far from guaranteed, in other words, that business success can be achieved even if the products made available are viable for the markets supplied. The case of the Hmong villagers where opium has been replaced by cabbages is instructive here. Pa Kluai village is the most well-known of these villages and it is home to Hmong people who have been nomadic in their history and undertake swidden - so-called 'slash and burn' - agriculture. Their lifestyles and agricultural behaviours are different from the Thai villagers and there have been opportunities for tension between the two communities. The Hmong people participated in a crop substitution programme by which opium was replaced by cabbages and 
some other food crops, which were to be sold in local markets. This was achieved through a mixture of persuasion and coercion.

There were some practical issues involved in this change of production. Poppy cultivation has not required any water other than rainwater. However, the cabbages did require extra water and this had an impact on conditions downslope, where the Thai villagers were living. Further, deforestation to provide extra land for cabbage growing was decried by conservation groups and a royally supported foundation - to achieve the same level of income as that obtained from growing poppy, the Hmong villagers need ten times as much land for their cabbages and the extensive use of pesticides and chemical fertilisers that have had a significant environmental impact (Kingham \& Wallon, 1995). The divisions in society that have resulted from this have not been helpful for its success (Renard, 1994). This negative impact contradicts the traditional swiddening farming methods, which, contrary to some public beliefs, are generally sustainable in nature.

\section{Thai-Chinese Green Energy Ltd. (Thailand)}

The Thai-Chinese Green Energy Ltd. (Thailand) company has been established in Nong Khai in the northeast of Thailand, where it has been growing and processing Inca Inchi nuts since 2015. The location was chosen for its convenient location and access to the nearby transportation infrastructure.

The company aligns potential Inca Inchi nut farmers with the necessary area, price, inputs and other equipment required for successful operations and it also ships the produce to a factory in the Xishuangbanna area of Yunnan province in China. That factory makes various types of medicines, cosmetics and beverages from the nuts.

The recommended method of production is, first, to prepare the land by using a lawn mower and without the use

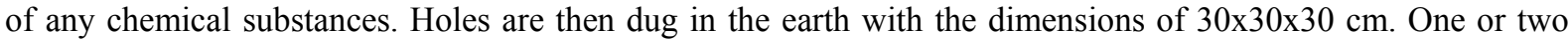
handfuls of manure or organic fertiliser (approximately 250 grams) are used for each hole. The plants are planted at a depth of some $15-20 \mathrm{~cm}$ and a two metre long bamboo stick is used to guide the plant's growth. One acre of land (approximately 0.4 hectares) can accommodate around 200-230 individual plants. After six to eight months of growth, the plants will start to produce sheathed seeds which can then be collected and dried for subsequent processing. They can usually produce seeds four to six times a year thereafter over a lifetime of 20-50 years. A single plant will produce $3-10 \mathrm{~kg}$ of fruit each and this equates to one rai of land ( 0.16 hectares) will yield 10,000 baht (US\$307) of product.

The company has managed to create a supply chain for nuts involving farms in Thailand with some supplementary growing in northern Myanmar, together with a manufacturing facility in China and retail in the southern part of that country. The level of success that has been achieved has depended upon not just the ability of the company founder to identify an opportunity and the ability to establish the relationships necessary to operate the business smoothly. The company is at the stage of experimentation with new products and product varieties with a view to determining which ones might be sustainable and to have a consistent level of demand.

\section{Entrepreneurialism}

The Academy of Management defines entrepreneurship as involving: "(a) the actors, actions, resources, environmental influences, and outcomes associated with the emergence of entrepreneurial opportunities and/or new economic activities in multiple organizational contexts, and (b) the characteristic actions, and challenges of owner-managers and their businesses (Academy of Management, 2011)."

Entrepreneurs themselves are commonly described as being forceful and energetic characters who are capable of identifying opportunities and able to gather to themselves the resources and capabilities necessary to exploit that opportunity. There is often something of a contradiction between the nature of an individual entrepreneur and the soft skills necessary to establish the relationships required to realise an individual opportunity such as the one discussed here.

One particular issue that will need to be considered is the issue of scaling production, distribution and consumption activities. It is one thing to create a small business selling a niche product in a specific market; it is quite a different thing to establish an extensive agricultural programme that will guarantee income to perhaps thousands of subsistence agricultural households.

\section{Discussion}

Much of the literature relating to entrepreneurialism relates to a business environment with at least a minimum level of physical and financial infrastructure that will support basic commercial activities. In the case of emerging markets and poor rural economies, it is often assumed that public sector extension services will supplement for or substitute the missing resources. However, in the case of Kachin State, warlike conditions and 
the absence of the effective rule of law mean that the only real source of support for farmers results from the proceeds of the opium trade and it is this trade which it is desired that inca inchi nuts will replace. Since it seems wholly unfeasible to replace something using proceeds that can only be provided by the continuation of that initial process. It seems hard to imagine, in other words, that the substitution process can take place without a significant revolution in social and commercial relations.

Successful implementation of substitution programmes in mainland Southeast Asia, insofar as these may be claimed to be sustainable, have achieved the success they have had through the application of some powerful competitive advantages, usually provided by an eternal organization. These external forces have included the international network created for Doi Chaang coffee and the unimpeachable authority of the Thai monarchy in the case of vegetables for export in northern Thailand. In these cases, it has only been when peaceful conditions have been imposed that the competitive advantage can be leveraged for the benefit of local people. Even so, this process removed a degree of agency from the individuals whose livelihood is most directly involved - they should be willing participants, of course, but the need for them to take control of the project is limited for a considerable period of the development of the project.

There is also the need to incorporate a form of triple bottom line accounting in determining the success of the inca inchi substitution project. Since the very fact that the farmers involved in opium production and distribution places them in a difficult and dangerous position. Consequently, it is not necessary for commercial success (presumably measured by a positive cash flow) to be achieved in the short term for the project to be considered successful overall at a preliminary stage. However, such a situation will not be sustainable without significant cash injections at some stage or, alternatively, a rapidly improving balance sheet. Again, success seems implausible without radical reorganization of existing social relations in some way.

\section{Conclusion}

This paper has considered the prospects for successfully substituting inca inchi nuts for opium and other narcotics in the Kachin State of northern Myanmar. It has been shown that significant obstacles are in the way of such a project and it does not seem likely that such a project can be successful under current circumstances. This analysis is supported by case studies of similar types of project in other parts of mainland Southeast Asia. However, the research here is qualitative in nature and that always raises the issue of the generalizability of the results obtained. Perhaps a wider and deeper dataset with a more expansive border of timeframe would indicate different possibilities.

It is clear that, given the stakes involved and difficulties in play, additional research is required to find alternative solutions to the current problem or a different way of framing the current situation such that other methods of trying to solve problems can be discerned. At the very least, inca inchi and other cash crop production in the area studied should be continued into the future.

\section{References}

Academy of Management. (2011). Academy of Management Division and Interest Group Domain Statements. Retrieved from aom.org/Content.aspx

Apolitical. (2017, June 5). Thailand's World-Beating Model Replaces Opium with Sustainable Crops. Retrieved from apolitical.co/solution_article/thailands-world-beating-model-replaces-opium-sustainable-crops/

Callahan, M. (2009). Myanmar's Perpetual Junta: Solving the Riddle of the Tatmadaw's Long Reign. New Left Review, 60(November-December), 27-63.

Choavy, P. A. (2013). Drug Trafficking in and out of the Golden Triangle: An Atlas of Trafficking in Southeast Asia. In The Illegal Trade in Arms, Drugs, People, Counterfeit Goods and Natural Resources in Mainland Southeast Asia (pp.1-32). London: IB Tauris.

Cooper, R. G. (1979). The Tribal Minorities of Northern Thailand: Problems and Prospects. Southeast Asian Affairs, 323-332. https://doi.org/10.1355/SEAA79Y

Dean, K. (2005). Spaces and Territorialities on the Sino-Burmese Boundary: China, Burma and the Kachin. Political Geography, 24(7), 808-820. https://doi.org/10.1016/j.polgeo.2005.06.004

Doi Tung. (2018). Sustainable Alternative Livelihood Development (SALD). Retrieved from http://www.dotung.org/sald_intro.php

Farrell, G. (1998). A Global Empirical Review of Drug Crop Eradication and United Nations' Crop Substitution and Alternative Development Strategies. Journal of Drug Issues, 28(2), 395-436. https://doi.org/10.1177/002204269802800207 
Inkey, M. (2018). Can Ethnic Armed Organizations Turn Guns into Ploughshares? Mizzima Weekly, 7(6), 40-41.

Kigham, R., \& Wallon, A. (1995). The Role of European Citizens' Associations in Strategies and Policies to Combat Drugs. In G. Estievenant (Ed.), Policies and Strategies to Combat Drugs in Europe: The Treaty on European Union: Framework for a New European Strategy to Combat Drugs? (pp. 311-318). Dordrecht, Boston, MA \& London: Martinus Nijhoff Publishers.

Lintner, B. (2002). Blood Brothers: Crime, Business and Politics in Asia. Chiang Mai: Silkworm Books. https://doi.org/10.1007/978-1-137-06294-9

Maï Savanh Lao. (2018a). Sacha Inchi. Retrieved from sachainchilaos.com

Maï Savanh Lao. (2018b). Popular Products. Retrieved from maisavanhlao.com $/ \mathrm{msl} / \mathrm{enl}$

Maï Savanh Lao. (2018c). Teaching Farms. Retrieved from maisavanhlao.com/msl/en/content/l-teaching-farms

Nascimento, A. K. L., Melo-Silveira, R. F., Dantas-Santos, N., Fernandes, J. M., Zucolotto, S. M., Rocha, H. A. O., \& Scortecci, K. C. (2013). Antioxidant and Antiproliferative Activities of Leaf Extracts from Plukunetia Volubilis Linneo (Euphorbiaceae). Evidence-Based Complementary and Alternative Medicines. https://doi.org/10.1155/2013/950272

On, Y. (2016). KIO-Owned Power Company Accused of Overcharging. Myanmar Times (May 23). Retrieved from http://www.mmtimes.com/national-news/204441-kio-owned-power-company-accused-of-overchargin g.html

Pendergrast, M. (2015). Beyond Fair Trade: How One Small Coffee Company Helped Trasnform a Hillside Village in Thailand. Vancouver: Greystone Books.

Pwint, N. L. H. (2018). An Illicit Business in Full Bloom in Hsi Hseng. The Irrawaddy (December 20). Retrieved from http://www.irrawaddy.org/photo-essay/illicit-business-full-flow-hsi-hseng.html

Renard, R. D. (1994). The Monk, the Hmong, the Forest, the Cabbage, Fire and Water: Incongruities in Northern Thailand Opium Replacement. Law and Society Review, 28(3), 657-664. https://doi.org/10.2307/3054085

Renard, R. D. (2001). Opium Reduction in Thailand, 1970-2000: A Thirty-Year Journey. Bangkok: UNDCP.

Verbruggen, Y. (2016). Pat Ja San: A Controversial Mission. Myanmar Times (March 21). Retrieved from http://www.mmtimes.com/in-depth/19566-pat-ja-san-a-controversial-mission.html

\section{Copyrights}

Copyright for this article is retained by the author(s), with first publication rights granted to the journal.

This is an open-access article distributed under the terms and conditions of the Creative Commons Attribution license (http://creativecommons.org/licenses/by/4.0/) 